\title{
Primates (Symphalangus syndactylus syndactylus, Macaca nemestrina, Macaca fascicularis) Population in the Ape Park Tourist Area Forest for Special Purpose of Aek Nauli
}

\author{
Johni Arisantana Barus ${ }^{1, *}$, Jafron Wasiq Hidayat ${ }^{2}$, and Maryono Maryono ${ }^{3}$ \\ ${ }^{1}$ Magister Program of Environmental Science, School of Postgraduate Studies, Diponegoro University, Semarang - Indonesia \\ ${ }^{2}$ Department of Biology, Faculty of Sains and Mathematics, Diponegoro University, Semarang - Indonesia \\ ${ }^{3}$ Department of Urban and Regional Planning, Faculty of Engineering, Diponegoro University, Semarang - Indonesia
}

\begin{abstract}
Forest for special purpose of Aek Nauli is an highland rainforest as habitat for primates and tourism area in Marsose, Sibaganding Village, Simalungun, Lake Toba Geopark in North Sumatra. As an endangered and protected species, siamang (Sympalangus syndactylus syndactylus) in the same habitat as pigtailed macaque (Macaca nemestrina) and long-tailed macaque (Macaca fascicularis). Nowadays, the siamang population is declining due to the conversion of forest to non-forests, forest fragmentation and illegal trade. Long-tailed macaque and pig-tailed macaque are agricultural pests that are economically harmful to communities around the forest. The primate population data is needed as input for the sustainable management strategy by stakeholders to further preserve forest areas and primate populations. This study was carried out for 3 months from May to July 2018. To determine the number of primate populations performed by the concentrated area method. Estimates of primate populations are: A. Siamangs; 1 group with 3 individuals, population size 0.06. Age structure of population 1 juvenile 1, 2 adults. B. Pig-tailed macaque; 3 groups with 65 individuals, population size 1.1. The age structure is 17 tillers, 17 adolescents and 31 adults. C. Long-tailed macaque; 3 groups with 23 individuals, population size 0.5. Age structure of 5 tillers, 7 adolescents and 11 adults.
\end{abstract}

Keywords: population, primates, Ape Park of Aek Nauli.

\section{Introduction}

Indonesia is an archipelagic country located on the equator and tropical climate allowing the growth of thousands of species of plants and animals in various aquatic and terrestrial ecosystems. Forests are one of the ecosystems where growth and development of biodiversity, especially primates. Forest management with all its contents must be in harmony with sustainable development for present and in the future beneficial from the economic, ecological and socio-economic aspects. One of the uses of forest and its potential is ecotourism and edutourism.

Forest for special purpose of Aek Nauli is a highland rainforest protected area which is a habitat for thousands flora and fauna. The forest is a catchment area of Lake Toba, located in Girsang Sipangan Bolon District, Simalungun Regency, North Sumatra. Altitude of $930-1,750$ meters from sea level, the slope of the land between $3-65 \%$ and is a historical area of the former Toba supra eruption 75,000 years ago. Geographically it is between $2^{\circ} 41^{\prime}-2^{\circ} 44^{\prime} \mathrm{LU}$ and $98^{\circ} 57^{\prime}-98^{\circ} 58^{\prime} \mathrm{BT}$. The dominant plants are Pinus merkusii, Eucaliptus deglupta,
Styrax sp., Shorea sp., Schima wallichii, Litsea sp., and Quercus sp. Various wild and protected animals such as Manis javanica, Panthera tigris sumatrae, Naemorhedus sumatraensis, Helarctos malayanus, Rusa unicolor, Muntiacus muntjak, Sympalangus syndactylus syndactylus and various species of birds.

In one of the Aek Nauli KHDTK spots in Marsose, Sibaganding Village, there is a secondary type of natural forest which is the primary transition habitat for three types of primates, namely siamang (Sympalangus syndactylus syndactylus), pig-tailed macaques (Macaca nemestrina) and long-tailed macaques (Macaca fascicularis). The area is strategically located on the side of the road from Medan, the capital of North Sumatra Province to Parapat as a tourist center of Lake Toba. Siamang $(S$. s. syndactylus) is a Sumatran endemic animal had population decline of $50 \%$ for 40 years (3 generations) mainly due to hunting for pet trade and habitat loss. In the last 50 years, siamangs have lost 70 to $80 \%$ of primary habitats that are protected areas. Mostly traded primate of the siamangs. Currently the remaining siamang populations in Sumatra are predominantly protected and conservation areas (Nijman and Geissman, 2008). Between 2000 and 2012, the rate of forest

\footnotetext{
* Corresponding author: baroes1204@gmail.com
} 
destruction was $49.85 \%$ in Sumatra and caused Hylobates to lose $54 \%$ of their forest habitat (Supriatna, et.al., 2017). Siamang is referred to key species in preserving forests because it functions as a seed dispersal.

Pig-tailed macaques (M. nemestrina) and longtailed macaques ( $M$. fascicularis) that inhabit the forest area form a primate unit as an element of strengthening the forest area as a natural tourist attraction. High annual reproduction (twice a year), the food supply is reduced caused the macaques primates became agricultural pests, and beg for food on the roadside. The adaptation of primate survival causes the loss of farmers economy, behavior changes, traffic congestion and traffic accident deaths.

Siamang ( $S$. s. syndactylus) is a protected primate in Indonesia. Endangered according to the 2014 IUCN (International Union on Conservation for Nature) Redlist Version. Based on the vulnerability of wildlife trade, siamang include Appendix I of CITES (Convention on International Trade in Endangered Species of Wild Fauna and Flora) (Nijman and Geissman, 2008).

Primates have genetic closeness with humans so primate management is carried out for tourism. Efforts to determine the primate population are used as a basis for further habitat management. Sustainable management of forest areas and all their potential can provide socioeconomic benefits for communities around the forest. Through this research, it is expected to be informed about the condition of primate density in the tourism area of Marsose Monkey Park, Sibaganding Village, Simalungun Regency, North Sumatra.

\section{Method}

\subsection{Time and Location}

The study was conducted in May-July 2018 in Monkey Park, Marsose, KHDTK Aek Nauli. Located at an altitude of 930 - 1,400 meters above sea level, a slope of $3-60 \%$ with an area of 50 ha, assuming the territorial boundary of the siamang, which according to Alikodra (2002) hylobatidae live in groups and defend its territory by sound or other special signs. The area of the Siamang (S. s. syndactylus) territorial area reaches 47 hectares (Supriatna and Ramadhan, 2016).

Average monthly rainfall of $206.5 \mathrm{~mm}$ and average annual rainfall of $2452 \mathrm{~mm}$ with the number of rainy days about 151 days / year. Maximum monthly temperatures range from $21.1-25^{\circ} \mathrm{C}$ with a minimum temperature range between $15.8-17.8^{\circ} \mathrm{C}$. Maximum relative humidity and average monthly minimum ranged between $67.5 \%$ - 85.6\% and 49.6\% - 73.9\% (Butarbutar and Harbagung, 1996).

\subsection{Materials and Methods}

The equipment used is GPS, binoculars, cameras and rollers meters. The data was collected using census method for siamangs and purposive sampling with concentrated point method which was supposed to be a gathering place for monkeys and long tail monkeys. Data collection includes the number of individuals, sexes and primate age classes. Data retrieval 7 times, twice a day in $06.30-10.00$ am and $03.00-06.00 \mathrm{pm}$.

\subsection{Analysis}

Data analysis with quantitative descriptive to calculate population size and density, age structure and sex ratio with equation as follows:

Population size $=\Sigma \mathrm{xi}$

Population Density $=(\Sigma x i) / A$

Age structure is calculated based on the percentage of the number of individuals in each age class, as follows:

Age structure $=(\Sigma x i) / \mathrm{n} \times 100 \%$

Annual Age Structure $=(\Sigma x i) / \Delta t$

$\mathrm{Sex}$ ratio $=\mathrm{Ji} / \mathrm{Bi}$

Description:

¿xi: number of individual -i

A: total area of observation

$\mathrm{n}$ : total number of individuals

$\Delta \mathrm{t}$ : lapse of age

$\mathrm{Ji}$ : the number of males

$\mathrm{Bi}$ : the number of females

To calculate the value of accuracy used spatial variation coefficient $(\mathrm{CV})$ value with the largest number of individuals by using equations that refer to Santosa et al (2014):

Accuracy $=100-\mathrm{CV} \%$

To determine the value of $\mathrm{CV}$ and other calculations using SPSS 22 software.

\section{Results}

\subsection{Population Size}

\subsubsection{Siamang (S. s. syndactylus)}

As endangered species, gigantic population data is indispensable for forest area management as a habitat for wildlife management. Based on the results of field data analysis, the size of the siamang population in Ape Park is 3 individuals in 1 group, consisting of a pair of adult and 1 individual child (Juvenile I). The accuracy value is $85.16 \%$. Population density is 0.06 individual per hectare, or the equivalent of 6 individuals per square $\mathrm{km}$ where still in normal condition. The density of the siamang population is between 2.4 - 24.6 individuals / sq $\mathrm{km}$ (O'Brien et al., 2004).

Table 1. Siamang population in Tourism Area Ape Park, Forest for special Purposes (KHDTK) Aek Nauli

\begin{tabular}{|c|c|c|c|c|c|}
\hline Groups & \multicolumn{2}{|c|}{ Adult } & $\begin{array}{c}\text { Juvenile } \\
2\end{array}$ & $\begin{array}{c}\text { Juvenile } \\
1\end{array}$ & Total \\
\cline { 2 - 6 } & Male & Female & & & \\
\hline 1 & 1 & 1 & - & 1 & $\mathbf{3}$ \\
\hline Total & $\mathbf{1}$ & $\mathbf{1}$ & - & $\mathbf{1}$ & $\mathbf{3}$ \\
\hline
\end{tabular}


Siamang adults over 9 years old with $10.5 \mathrm{~kg}$ female body and $12.8 \mathrm{~kg}$ male. Males are distinguished by females through scrotal hair that dangles between the two thighs of the male individual. The female is relatively smaller than the male and weighs approximately $92 \%$ of the male's weight. According to Gittins and Raemaekers (1980), the age group of siamangs is divided into 5 groups, consisting of: Infant : 0-2 years old, very small body size and always in a female sling. The male will take over the baby's care in the second year. Juvenile 1: 2-4 years old, small body and travel alone but always close to the mother. Juvenile 2: 4 - 6 years old, medium size and doing activities not far from the group. Sub-adult: more than 6 years, began to separate from the group but still in a single group. Not sexually mature and almost the same body as adults.

Population size of siamang in a group consists of 2 - 10 individuals and has a territorial area about 47 ha (Supriatna and Ramadhan, 2016). The increasing number of siamang in the same territorial area is difficult because Hylobatidae has the character of maintaining its territory with sound or other special signs (Alikodra, 2002). Pregnancy between 200 - 210 days, birth distance about 3 - 4 years, and siamang survive up to 35 years. Siamang is a monogamous animal, so the population tends to be small and the presence of children gives hope to the sustainability of the population.

\subsubsection{Pig-tailed macaque (M. nemestrina)}

The population size is 65 individuals divided into 3 groups, namely group 1 , group 2 and group 3 in the table. The population density was 1.1 people per hectare with accuracy the value of $91.85 \%$. Follow-on studies for the distribution, abundance and threat are required for conservation measures due to the status of the CITES Appendix II primates (Richardson, et.al, 2008).

Table 2. Pig-tailed macaque population in Tourism Area Ape Park, Forest for special Purposes (KHDTK) Aek Nauli

\begin{tabular}{|c|c|c|c|c|c|}
\hline \multirow{2}{*}{ Groups } & \multicolumn{2}{|c|}{ Adult } & \multirow{2}{*}{ Adolenscents } & Children & Total \\
\cline { 2 - 5 } & Male & Female & & & \\
\hline 1 & 5 & 6 & 6 & 6 & $\mathbf{2 3}$ \\
\hline 2 & 4 & 5 & 5 & 5 & $\mathbf{1 8}$ \\
\hline 3 & 5 & 6 & 6 & 6 & $\mathbf{2 4}$ \\
\hline Total & 14 & 17 & 17 & 17 & $\mathbf{6 6}$ \\
\hline
\end{tabular}

Adults have a body length of 450 - $600 \mathrm{~mm}$ with 7$9 \mathrm{~kg}$ male weight and 4-6 $\mathrm{kg}$ of female. The female is a nanny and is close to her child. The baby is black and in a few months will become brownish. On field observation, the baby will always be carried by the mother in searching for feed. Children and adolescents will be looking for food to follow the group with a size smaller than adults.

Pig-tailed macaque ( $M$. Nemestrina) first marriage is about 4-4,5 years old, nursing spacing 24 - 48 months. The duration of pregnancy for 162-186 days and the majority of each birth resulted in one child. The period of nurturing for 7-17 months, 32-40 days of age and age of ape in maintenance area reaches 26 years (Supriatna and Ramadhan, 2016).

It recognizes the social hierarchy where the highest position occupies the most dominant adult male individual (Wahyudin, 1990). Grouped into "Multimales Group", which have more than one adult male in one group. These factors makes this macaque population more than the siamang.

\subsubsection{Long-tailed Macaque (M.fascicularis)}

The population size is 23 individuals divided to 3 groups namely group 1, group 2 and group 3 as in table 3. Population density is 0.5 individuals per hectare, with accuracy value $84.77 \%$.

Table 3. Long-tailed macaque population in Tourism Area Ape Park, Forest for special Purposes (KHDTK) Aek Nauli

\begin{tabular}{|c|c|c|c|c|c|}
\hline \multirow{2}{*}{ Groups } & \multicolumn{2}{|c|}{ Adult } & Adolenscents & Children & Total \\
\cline { 2 - 3 } & Male & Female & & & \\
\hline 1 & 1 & 2 & 2 & 2 & 7 \\
\hline 2 & 1 & 3 & 2 & 1 & $\mathbf{7}$ \\
\hline 3 & 1 & 3 & 3 & 2 & $\mathbf{9}$ \\
\hline Total & 3 & 8 & 7 & 5 & $\mathbf{2 3}$ \\
\hline
\end{tabular}

Long-tailed macaque are diurnal and semiarboreal. The ranges vary from 10 to 80 ha in terrestrial forests and 125 ha in mangrove forests (Supriatna and Ramadhan, 2016). Their morphology is about the same length as the length of the body. The body length is $385-$ $648 \mathrm{~mm}$. Tail length ranges from 400 to $655 \mathrm{~mm}$ in males and females Weight of adult female body between 2,500-7,000 grams, while adult males are about 4,70014,000 grams (Rowe, 1996 in Fuentes et.al, 2007The age division according to Bismark (1984), aged 0-1 year old puppy, black-colored, smallest and always in a female sling and red ears.At six weeks the color of hair is brown.English individual, aged 4-6 years. in the head, not immature sexually Adult individuals, aged over 6-15 years old, skin hair turns yellowish, gray or dark brown, and on the underside of the abdomen and inner legs are always brighter Based on the morphological features, females adult visible nipples, and large scrotum adult males are clearly visible, pregnancy period 153-179 days and generally giving birth to one child, where the life span reaches 15 years.

\subsection{Age Structure}

To know the success of wildlife breeding can be known from the age structure (Alikodra, 2002). The group of siamang is led by an adult male who is in charge of keeping a child and a more active female for food during the day. Siamang at research location there is 1 group related to its territorial area (Supriatna and Ramadhan, 2016).

In primate pig-tailed macaque, there are 3 groups, each group is led by 1 adult male which has the largest body and has character of supervising male and female adult and other group members. Each member of the 
group has a strong bond between mother and baby, fellow males and young males and between adult males and adult females. On field observations, every adult female has a child held on the front. There is each adolescent of every single adult female parent.

Long tail macaque have 3 groups, each group being led by 1 adult male. In group 1 , each adult female has 1 child, in group 2 there is 1 child and 3 group, there are 2 children. According to the field officer, the adult females already have an old age. In each group there are adolescent individual based on the number of mature females.

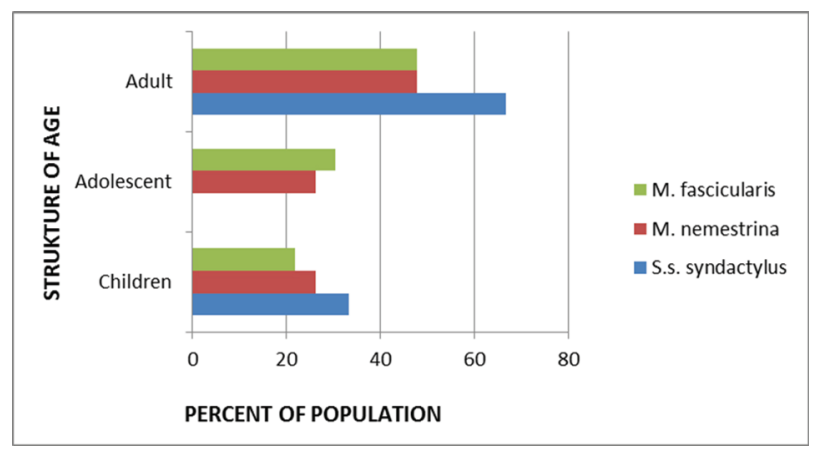

Fig 1. Primate age structure in Tourism Area Ape Park, Forest for special Purposes (KHDTK) Aek Nauli

The largest percentage of age is found in adult age classes in each species of primate. Siamang has no individual class of children because of the distance between births between 3-4 years. While in primates macaque (pig-tailed and long tailed) have a complete composition of age structure. This shows the reproduction process of these macaca primates in good condition. The number of long-tailed macaque populations has fewer than pig-tailed macaque because of lower competition and hierarchy, resulting in less food and space opportunities. Other factors are influenced by the amount of food supply (Kuswanda and Gertiasih, 2016). Based on observations in the field, groups of similar primates groups spread in Forest for Special Purposes of Aek Nauli.

Table 4. Important value index vegetation primate feed.

\begin{tabular}{|l|l|l|l|}
\hline No & Family & $\mathbf{( \% )}$ & Information \\
\hline 1 & Lauraceae & 43,13 & -- \\
\hline 2 & Myrtaceae & 35,21 & Food \\
\hline 3 & Moraceae & 31,87 & Food \\
\hline 4 & Euphorbiaceae & 28,65 & Food \\
\hline 5 & Fagaceae & 18,99 & Food \\
\hline 6 & Theaceae & 18,90 & Food \\
\hline 7 & Sapotaceae & 10,28 & Food \\
\hline 8 & Styraceae & 10,70 & -- \\
\hline 9 & Arecaceae & 9,25 & Food \\
\hline 10 & Asteraceae & 9,08 & -- \\
\hline TOTAL & $\mathbf{2 1 6 , 0 6}$ & \\
\hline
\end{tabular}

Based on vegetation data, the majority of primate feed sources are fruit wood plants. In the fruiting season, all primates gather in the forest and are not found wandering the streets and farm land. Fruit season only lasts 1 or twice a year, so the need for reduced primate feed in the season does not bear fruit.

Calculation of the average annual, comparison of adult: adolescent: child is Table 5 .

Table 5. Calculation of primate age structure based on annual mean

\begin{tabular}{|l|l|l|l|l|l|}
\hline Primates & $\begin{array}{l}\text { Age } \\
\text { Structure }\end{array}$ & $\begin{array}{l}\text { Age } \\
\text { Range } \\
\text { (Years } \\
\text { ) }\end{array}$ & $\begin{array}{l}\text { Age } \\
\text { laps } \\
\mathrm{e}\end{array}$ & $\begin{array}{l}\text { Number of } \\
\text { Individuals }\end{array}$ & $\begin{array}{l}\text { Annu } \\
\text { al } \\
\text { Mean }\end{array}$ \\
\hline \multirow{2}{*}{$\begin{array}{l}\text { S.s.synda } \\
\text { ctylus }\end{array}$} & Adult & $9-35$ & 26 & 2 & 0,076 \\
\cline { 2 - 6 } & Adolescent & $4-9$ & 5 & - & 0 \\
\cline { 2 - 6 } & Children & $0-4$ & 4 & 1 & 0,25 \\
\hline \multirow{2}{*}{$\begin{array}{l}\text { M.nemest } \\
\text { rina** }\end{array}$} & Adult & $4-25$ & 21 & 31 & 1,47 \\
\cline { 2 - 6 } & Adolescent & $2-4$ & 2 & 17 & 8,5 \\
\cline { 2 - 6 } & Children & $0-2$ & 2 & 17 & 8,5 \\
\hline \multirow{2}{*}{$\begin{array}{l}\text { M.fascicu } \\
\text { laris** }\end{array}$} & Adult & $6-15$ & 11 & 11 & 1 \\
\hline & Adolescent & $4-6$ & 2 & 7 & 3,5 \\
\hline & Children & $0-4$ & 4 & 5 & 1,25 \\
\hline
\end{tabular}

The more individuals in the younger age class can be an indicator of the population will increase with the assumption of mortality at every age interval is constant (Santoso, et.al. 2008 in Rahmawati and Jafron, 2017).

The age class of a siamang is not found in adolescent classes, and tends to increase from adulthood to puppies. Caused due to birth distance between 3 - 4 years and birth of 1 child during pregnancy (Nijman, 2008). Due to the protected and endangered conservation status, regular population dynamics monitoring is required.

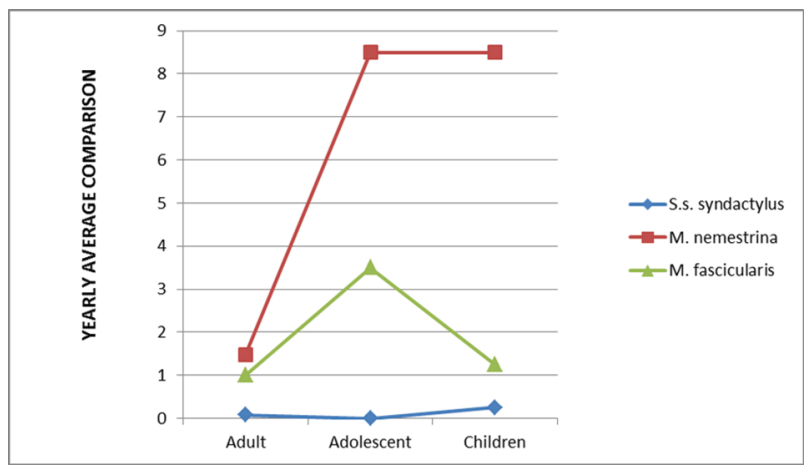

Fig 2. Comparison of mean annual primates to age classes

Age structure increased from adult to adolescent and stable to child's age class indicates stable population tends to increase in the future. Different things happen to long-tailed monkeys, where adult age classes increase to adolescence grade and decrease to child class. This can be due to various factors such as due to the condition of the river in tourism area Apes Park, Marsose is rain-fed, resulting in drought during the dry season and longtailed monkeys love the river. Qualitative data from interviews with field officer and field observations, adult female long-tailed monkeys have entered a relatively old age. 


\section{Conclusions and suggestions}

\subsection{Conclusions}

The density and age strukture of primate populations in Tourism Area Apes Park, Marsose Forest for Special Purposes of Aek Nauli are: S.s.syndactylus: 0.06 individuals per hectare with 1 group composition consisting of 1 adult male, 1 adult female and 1 juvenile 1. The age structure of siamangs is $67 \%$ adult and $33 \%$ child M.nemestrina: population density 1.1 individuals per hectare, consisting of 3 groups ie group 1, group 2 and group 3. The highest population size is group of 3 (24 individuals). Age structure is $47.7 \%$ adult, adolescent $26.15 \%$ and child $26.15 \%$. M. fascicularis: population density 0.5 individuals per hectare, consisting of 3 groups and the highest group in group 3 of 9 individuals. Age structure is adult $47,8 \%$, adolescent $30,4 \%$ and child $21,7 \%$.

Preservation of primates and their habitat will contribute to the use of environmental services such as ecotourism, water use, and carbon trading.

\section{.4 .2 Suggestions}

In order to do further research to determine the carrying capacity of habitat and level of competition to primate populations in Monkey Park area, Marsose Tourism Area Apes Park, Marsose Forest for Special Purposes of Aek Nauli .

\section{Acknowledgments}

The authors would like to thank Bappenas of the Republic of Indonesia for the opportunity and funding.

\section{Bibliography}

1. Alikodra, HS. 2002. Wildlife Management Ch.I. Bogor: Penerbit Fakultas Kehutanan IPB. Bogor..

2. Alikodra, HS. 2010. Wildlife Management Techniques in Order to Maintain Biodiversity in Indonesia.Bogor; IPB Press.

3. Butarbutar, T. dan Harbagung. 1996. Study of Soil Properties for Eucalyptus urophylla Plant in North Sumatra. Buletin Penelitian Kehutanan 12 (2) : 171-180. BPK Pematang Siantar.
4. Gittins, S.P., Raemakers, S.I.J. 1980. Siamang, Lar and Agile Siamangs. Di dalam Chivers DJ, editor. Malayan Forest Pimates: Ten years study in tropical rain forest. Plenum Press. New York.

5. Kuswanda, W. dan R. Gertiasih, 2016. Carrying Capacity and Growth of Siamang Population (Hylobates syndactylus Raffles, 1821) at Dolok Sipirok Nature Reserve, North Sumatra. Buletin Plasma Nutfah Vol. 22 No. 1,:67-80.

6. Nijman. V., and Geissman,T. 2008, Symphalangus syndactylus, Siamang, The IUCN Red List Of Threatened Species 2008, http://www.iucnredlist. org/details/39779/0 , accesed 27 March 2018.

7. O'Brien, T.G., M.F. Kinnaird., A. Nurcahyo and M. Iqbal., 2006. Fire, demography and the persistence of siamang (Symphalangus syndactylus: Hylobatidae) in a Sumatran rainforest. Animal Conservation 6(2):115-121.

8. Rahmawati, Ervina dan J. W Hidayat, 2017. Density of Java Lutung Population (Trachypithecus auratus) at Ulolanang Nature Reserve of Batang Regency, Proceeding Biology Education Conference, Volume 14. Nomor 1, p: 64-69.

9. Richardson, M., Mittermeier, RA, Rylands, $A B$ and Konstant,B.2008. Macaca nemestrina. Red list IUCN Endangered Species 2008:e.T12555A33568

92. http://dx.doi.org/10.2305/IUCN.UK.2008.RL TS.T12555A3356892.en accesed 28 March 2018 .

10. Rinaldi, D. 1992. The use of Triangle and Concentration Count methods in the Cibbon distribution and population (Hylobatidae). Media Konservasi Vol.IV (1), 9-21

11. Supriatna, J. dan E. Hendras W., 2000. Indonesia Primates Field Guide. Yayasan Obor Indonesia, Jakarta. First Edition

12. Supriatna, J. Dan R. Ramadhan., 2016. Tourism Primate Indonesia, Yayasan Pustaka Onor Indonesia, Jakarta.

13. Supriatna, J., A.A. Dwiyahreni, N. Winarni, S. Mariati and C. Margules., 2017. Deforestation of primate Habitat on Sumatra and Adjacent Islands, Indonesia, Primate Conservation. 